\title{
EFFECT OF INTRODUCING OZONE PRIOR TO ELEMENTAL CHLORINE FREE BLEACHING OF WHEAT STRAW PULP ON PULP, PAPER AND EFFLUENT PROPERTIES
}

\author{
SANDEEP KUMAR TRIPATHI, ${ }^{*}$ NISHI KANT BHARDWAJ ${ }^{* *}$ and HIMADRI ROY GHATAK* \\ *Department of Chemical Engineering, Sant Longowal Institute of Engineering and Technology, Longowal \\ 148106, Sangrur, Punjab, India \\ **Avantha Centre for Industrial Research and Development, Paper Mill Campus, \\ Yamuna Nagar 135001, Haryana, India \\ $\bowtie$ Corresponding author: S. K. Tripathi, sandeep@avantharesearch.org
}

Received June 16, 2018

Ozone has been considered for the development of greener processes for hardwood and softwood pulps. This paper summarizes the results obtained using ozone bleaching on wheat straw pulp, followed by elemental chlorine free bleaching. This work evaluated the effect of introducing ozone bleaching on the optical properties of wheat straw pulp, along with the content of metal ions and hexenuronic acid in the pulp, pulp strength and morphological properties, as well as effluent properties. Introducing an ozone stage into the ECF bleaching sequence of wheat straw pulp improved pulp brightness by 2.5 units, pulp whiteness - by 4.0 units, while reducing the hexenuronic acid content by $21.6 \%$ and brightness reversion - by $34.8 \%$, and allowed attaining physical strength and morphological properties comparable to those of the control. The introduction of the ozone treatment reduced the $\mathrm{Fe}, \mathrm{Cu}$ and $\mathrm{Mn}$ content in the pulp by $6 \%$, $11 \%$ and $31 \%$, respectively. It also significantly reduced the COD in the bleaching filtrate by $41.2 \%$, BOD - by $39.6 \%$, colour level - by $57.9 \%$ and $\mathrm{AOX}$ - by $47.3 \%$, compared to the control. The introduction of ozone prior to elemental chlorine free bleaching of wheat straw pulp was demonstrated to improve effluent quality, while yielding comparable pulp and paper properties.

Keywords: elemental chlorine free bleaching, ozone bleaching, wheat straw pulp, viscosity, brightness, kappa number

\section{INTRODUCTION}

Ozone bleaching is now well established for hardwood and softwood pulps, being considered as one of the best available technology from the environmental point of view. Presently, about 24 wood based mills worldwide are producing about 8 million tons of ozone bleached pulp. ${ }^{1}$ Unfortunately, none of the agro based mills is reported to use ozone as bleaching chemical in their bleaching sequence. The reason may be the lower physical strength properties of agro residue pulps, as compared to those of wood pulps. Ozone is a very strong oxidizing agent, which reacts with all the chemical constituents present in the cellulosic pulp. Though the reaction of ozone is more selective towards lignin, as compared to carbohydrates, the formation of intermediate radicals during ozone bleaching resulted in the deterioration of carbohydrates. ${ }^{2,3}$ The formation of radicals during the ozone bleaching of pulps not only promotes an unwanted attack on carbohydrates, but also decomposes the ozone and thereby increases its consumption. The reaction of ozone with the carbohydrate fraction of the pulp reduced pulp viscosity, which ultimately resulted in lower strength properties of paper. ${ }^{4}$ Ozone bleaching of pulps, such as agro residue based raw material pulps, having lower physical strength properties is suposed to be more critical.

Higher degradation of carbohydrates during ozone bleaching of agro residue pulps may make the pulp unusable for papermaking. In the present study, the effect of introducing ozone in elemental chlorine free (ECF) bleaching of wheat straw pulp is investigated.

Until now, the majority of the research studies on ozone bleaching were performed on softwood 
or hardwood kraft pulps. ${ }^{5-9}$ Very scanty literature is available on the ozone bleaching of non-wood pulps. ${ }^{10-12}$ Earlier, the main parameters affecting the ozone bleaching of wheat straw pulp were determined using the Plackett-Burman design, ${ }^{13}$ and the ozone bleaching conditions for wheat straw soda pulp were further optimized using response surface methodology. ${ }^{14}$

This paper describes the introduction of ozone in the ECF bleaching of wheat straw pulp on the optical properties, content of metal ions and hexenuronic acid, strength and morphological properties of the pulp, as well as on effluent properties. The results of the study will be relevant to the pulp and paper industry using ECF bleaching sequence without ozone. Present study will be more beneficial for agro based paper mills planning to improve product and effluent quality.

\section{EXPERIMENTAL Material used}

For the study, wheat straw was collected from North India and was separated from grain using power driven threshing machines.

\section{Physical and chemical analysis of wheat straw}

Bulk density of the wheat straw was determined as per Tappi Useful Method UM 23 (2015), generally used to determine the bulk density of wood chips. The sample of wheat straw was prepared for chemical analysis as per Tappi T $264 \mathrm{~cm}-07$. Different chemical constituents of wheat straw, such as cellulose, hemicelluloses, holocellulose, acid insoluble lignin and acetone extractives, were analyzed following the test methods of Updegraff (1969), ${ }^{15}$ Deschatelets (1986), ${ }^{16}$ Wise (1946), ${ }^{17}$ along with Tappi T 222 om-11 and Tappi T $204 \mathrm{~cm}-07$, respectively. The ash content, acid insolubles, silica content, $1 \%$ sodium hydroxide solubility and hot water solubility were determined using Tappi T $211 \mathrm{om}-12$, Tappi T $244 \mathrm{~cm}-11$, Tappi T $245 \mathrm{~cm}-07$, Tappi T $212 \mathrm{om}-12$ and Tappi T $207 \mathrm{~cm}-$ 08 , respectively.

\section{Pulping of wheat straw}

Following pulping conditions were kept for producing unbleached pulp of about 14 kappa number in the lab autoclave digester using soda pulping process: active alkali dose as $\mathrm{NaOH}-16.0 \%$, anthraquinone dose $-0.05 \%$, material to liquor ratio $1: 4$, pulping time at maximum temperature $-20 \mathrm{~min}$, maximum pulping temperature $-166{ }^{\circ} \mathrm{C}, \mathrm{H}$ factor 225. After completion of pulping the digested material was disintegrated and washed with hot water to remove the dissolved substances. Prior to further processing the pulp was screened using $0.15 \mathrm{~mm}$ slotted screen in a laboratory Somerville type pulp fractionator as per Tappi test method T $275 \mathrm{sp}-12$.

\section{Oxygen delignification of pulp}

Single stage oxygen delignification (ODL) of the screened pulp was carried out in a pressurized reactor with stirring during the reaction. The following conditions were maintained during the ODL stage: sodium hydroxide dose of $1.5 \%$ per o.d. pulp, oxygen dose of $1.5 \%$ per o.d. pulp, pulp consistency of $10 \%$, time of $60 \mathrm{~min}$ and temperature of $85^{\circ} \mathrm{C}$.

\section{Ozone treatment of pulp}

Before the ozone treatment, the pulp was preacidified to a $\mathrm{pH}$ of about 2.0 , using $2 \mathrm{~mol} / \mathrm{L}$ sulfuric acid at a pulp consistency of about $5 \%$, then centrifuged to a consistency of about $30 \%$, before being fluffed. The ozone stage bleaching of the pulp was performed in a reactor with continuous ozone gas injection through small apertures at the bottom and under stirring to ensure proper interaction of the ozone gas with the fluffed pulp. The following conditions were maintained during the ozone bleaching of pulp: consistency of $30 \%, \mathrm{pH}$ of 2.0 , temperature of $50{ }^{\circ} \mathrm{C}$, time of $3 \mathrm{~min}$, ozone gas flow rate of $1.5 \mathrm{~L} / \mathrm{min}$, ozone gas concentration of $0.045 \mathrm{~g} / \mathrm{L}$.

The residual ozone left after the reaction and the ozone dose applied to the pulp were measured by the iodometric wet chemistry method. ${ }^{18}$ An alkali treatment was done on the pulp, after the ozone treatment, in low density polyethylene bags, using the following conditions: temperature of $75{ }^{\circ} \mathrm{C}$, consistency of $10 \%$, time of $30 \mathrm{~min}$ and sodium hydroxide dose of $1.5 \%$ per o.d. pulp. Alkali extraction of the pulp was then carried out. The pulp was washed thoroughly prior to determining its kappa number, brightness and viscosity.

\section{Bleaching of pulp}

Elemental chlorine free bleaching of oxygen delignified and ozone treated wheat straw pulps was carried out following a $\mathrm{D}_{0} \mathrm{E}_{\mathrm{OP}} \mathrm{D}_{1}$ sequence using the conditions summarized in Table 1 . The different stages were performed in sealed polythene bags placed in a thermostat-controlled water bath.

\section{Analysis of pulp parameters}

Different properties of the wheat straw pulp, such as kappa number, viscosity, brightness, whiteness, hexenuronic acid (HexA) and freeness, were analyzed following Tappi test methods T 236 om-06, T 230 om08 , T 525 om-12, T 560 om-05, T 560 om-05 and T 227 om-09, respectively.

The brightness reversion tendency of the bleached pulps was evaluated in terms of post colour (P.C.) number calculated from the brightness value measured before and after aging. Standard accelerated aging of pulps was carried out by placing pulp sheets at $105^{\circ} \mathrm{C}$ for $4 \mathrm{~h}$ as per Tappi UM 200. The P.C. number of the pulp was calculated using the equation described by Giertz, ${ }^{19}$ as given below: 
P.C. number $=\left[\frac{\left(1-R_{2}\right)^{2}}{2 R_{2}}-\frac{\left(1-R_{1}\right)^{2}}{2 R_{2}}\right] 100$

where $R_{1}$ is the brightness before the aging test and $R_{2}$ is the brightness afterwards.

The content of transition metals ( $\mathrm{Fe}, \mathrm{Cu}, \mathrm{Mn}, \mathrm{Zn}$ and $\mathrm{Mg}$ ) in the pulp was determined using a NovAA 300 spectrophotometer manufactured by Analytik Jena
AG after the acid digestion of the samples, according to Tappi test method T 266 om-06. The morphological properties of the pulp fibers were measured using an L\&W fiber tester as per Tappi test method T 271 om07.

Table 1

Conditions of $\mathrm{D}_{0} \mathrm{E}_{\mathrm{OP}} \mathrm{D}_{1}$ sequence

\begin{tabular}{lccc}
\hline Particulars & $\mathrm{D}_{0}$ stage & $\mathrm{E}_{\mathrm{OP}}$ stage & $\mathrm{D}_{1}$ stage \\
\hline Temperature $\left({ }^{\circ} \mathrm{C}\right)$ & 55 & 80 & 75 \\
Time $(\min )$ & 45 & 120 & 180 \\
Consistency $(\%)$ & 10 & 10 & 10 \\
Sodium hydroxide $(\%)$ & - & $1.3^{\#} / 0.7^{*}$ & - \\
Hydrogen peroxide $(\%)$ & - & 0.5 & - \\
Chlorine dioxide $(\%)$ & $0.88^{\#} / 0.46^{*}$ & - & 0.5 \\
\#Dose of chemicals used for bleaching oxygen delignified pulp; ${ }^{*}$ Dose of chemicals used for \\
bleaching ozone treated pulp re
\end{tabular}

Paper handsheets were prepared from the refined and unrefined pulps, as per TAPPI T 205 sp-06 using a British type handsheet former. Refining the pulps were carried out in a PFI mill (Hamjern Maskin A/S, Hamar, Norway; PFI mill no. 616), applying 100 revolutions as per Tappi test method T $248 \mathrm{sp}-08$. Prior to analyzing the physical strength properties, as per Tappi test method T $220 \mathrm{sp}-06$, the handsheets were conditioned at $27 \pm 2{ }^{\circ} \mathrm{C}$ and $65 \pm 5 \%$ relative humidity as per ISO: 187.

\section{Analysis of effluent parameters}

The filtrates (effluent) generated in each stage of bleaching $\left(\mathrm{D}_{0}, \mathrm{E}_{\mathrm{OP}}\right.$ and $\mathrm{D}_{1}$ stages) were mixed in the corresponding volumetric proportions. The combined effluent was characterized with regard to chemical oxygen demand (COD), biological oxygen demand (BOD), as well as colour and adsorbable organic halide (AOX), using test methods IS: 3025 (Part-58), IS: 3025 (Part-44), APHA: $2120 \mathrm{C}$ and ISO: 9562:2004, respectively.

\section{RESULTS AND DISCUSSION Physical and chemical properties of wheat straw}

The physical and chemical properties of the wheat straw used in the present study, determined on oven dried material basis, are given in Table 2. Wheat straw has $64.5 \mathrm{~kg} / \mathrm{m}^{3}$ bulk density, which is marginally higher than the reported values of $52-53 \mathrm{~kg} / \mathrm{m}^{3}$ for chopped wheat straw. ${ }^{20}$ Bulk density is an important characteristic of raw materials, which directly influences the transportation cost and the storage area. ${ }^{21,22}$ Wheat straw has $2.3 \%$ acetone extractives and 9.9\% water soluble extractives, which are comparable with earlier reported values for wheat straw and hardwood species, but lower than the values reported for softwood species. $^{23,24}$ Acetone removes mainly resin material, including the fatty and resin acids, sterols, waxes and fats present in the raw material. Subsequently, hot water is used to extract tannins, gums, sugars, starches and colouring matter. Hot water soluble extractives of wheat straw mainly contain free fatty acids, waxes, sterols, triglycerides, diglycerides, sterol esters, resin acid and phenolic compounds. ${ }^{25}$ Wheat straw was found to contain $36.6 \%$ cellulose, $28.1 \%$ hemicelluloses, $16.4 \%$ lignin and $7.1 \%$ inorganics, which is comparable with the values reported earlier by other researchers for wheat straw obtained from different places. ${ }^{26,27}$

Pulps produced from agricultural residues, except sugarcane bagasse, are difficult to bleach to a high brightness (+85\% ISO) level. Wheat straw pulp was reported to reach $84.8 \%$ ISO brightness, using 10 different conventional and elemental chlorine free (ECF) bleaching sequences. ${ }^{28}$ Oxygen delignified wheat straw pulp was bleached to $84.5 \%$ ISO brightness by the ECF bleaching sequence $\left(\mathrm{D}_{0} \mathrm{E}_{\mathrm{OP}} \mathrm{D}_{1}\right)$, using optimized bleaching chemicals and conditions.

Based on earlier studies and the results of the present study, it appears that wheat straw pulp has a brightness ceiling at about $85 \%$ ISO brightness level, when using ECF bleaching sequences without ozone. With the introduction of ozone, prior to the ECF bleaching sequence, pulp 


\section{SANDEEP KUMAR TRIPATHI et al.}

brightness was increased by 2.5 units to $87.0 \%$ ISO. The whiteness of the pulp was also improved by 4.0 units from 79.4 to 83.4 CIE units. The improvement in the pulp brightness and whiteness of the ECF bleached pulps after introducing ozone in the previous stage may be due to the additional removal of HexA and metal ions in the ozone stage.

Table 2

Physical and chemical properties of wheat straw

\begin{tabular}{lc}
\hline Particulars & Results \\
\hline Bulk density $\left(\mathrm{kg} / \mathrm{m}^{3}\right)$ & $64.5 \pm 1.9$ \\
$1 \%$ NaOH solubility (\%) & $28.2 \pm 0.8$ \\
Hot water solubility (\%) & $11.1 \pm 0.7$ \\
Acetone extractives (\%) & $2.3 \pm 0.2$ \\
Water soluble extractives (\%) & $9.9 \pm 0.6$ \\
Hemicelluloses (\%) & $28.1 \pm 0.3$ \\
Cellulose (\%) & $36.6 \pm 0.8$ \\
Lignin (\%) & $16.4 \pm 0.3$ \\
Holocellulose (\%) & $64.4 \pm 1.0$ \\
Ash (\%) & $7.1 \pm 0.2$ \\
Acid insolubles $(\%)$ & $4.6 \pm 0.3$ \\
Silica $(\%)$ & $4.1 \pm 0.2$ \\
\hline
\end{tabular}

Table 3

Bleaching of pulp using ECF sequence $\mathrm{D}_{0} \mathrm{E}_{\mathrm{OP}} \mathrm{D}_{1}$ with and without ozone

\begin{tabular}{|c|c|c|}
\hline \multirow{2}{*}{ Particulars } & \multicolumn{2}{|c|}{ Results } \\
\hline & ECF (control) & ECF (with ozone) \\
\hline \multicolumn{3}{|c|}{ ODL stage } \\
\hline Kappa no. & \multicolumn{2}{|c|}{8.9} \\
\hline Brightness (\%ISO) & \multicolumn{2}{|c|}{47.1} \\
\hline Viscosity (mPas) & \multicolumn{2}{|c|}{12.9} \\
\hline \multicolumn{3}{|c|}{ Z stage } \\
\hline Kappa no. & - & 4.7 \\
\hline Brightness (\%ISO) & - & 61.5 \\
\hline Viscosity (mPas) & - & 10.8 \\
\hline \multicolumn{3}{|c|}{$D_{o}$ stage } \\
\hline Final $\mathrm{pH}$ & $2.2 \pm 0.1$ & $2.2 \pm 0.1$ \\
\hline Residual $\mathrm{ClO}_{2}(\mathrm{ppm})$ & $16.7 \pm 0.7$ & $13.6 \pm 0.5$ \\
\hline \multicolumn{3}{|c|}{$E_{O P}$ stage } \\
\hline Final $\mathrm{pH}$ & $10.6 \pm 0.1$ & $10.5 \pm 0.1$ \\
\hline Residual $\mathrm{H}_{2} \mathrm{O}_{2}(\mathrm{ppm})$ & $34.0 \pm 2.0$ & $66.0 \pm 2.0$ \\
\hline Brightness (\%ISO) & $82.3 \pm 0.2$ & $84.2 \pm 0.1$ \\
\hline Kappa number & $2.3 \pm 0.1$ & $1.5 \pm 0.1$ \\
\hline \multicolumn{3}{|c|}{$D_{1}$ stage } \\
\hline Final $\mathrm{pH}$ & $3.7 \pm 0.1$ & $3.8 \pm 0.1$ \\
\hline Residual $\mathrm{ClO}_{2}$ (ppm) & $19.0 \pm 2.0$ & $26.3 \pm 2.5$ \\
\hline Brightness (\%ISO) & $84.5 \pm 0.2$ & $87.0 \pm 0.2$ \\
\hline P.C. number & $0.46 \pm 0.04$ & $0.30 \pm 0.01$ \\
\hline CIE whiteness & $79.4 \pm 0.3$ & $83.4 \pm 0.3$ \\
\hline Viscosity (mPas) & $10.3 \pm 0.1$ & $9.7 \pm 0.1$ \\
\hline
\end{tabular}

The metal ions present in the pulp form strongly coloured complexes with the lignin structures and cause a significant decrease in pulp brightness, while the presence of a high amount of HexA also reduces the brightness of pulp. ${ }^{29,30}$
When introducing ozone prior to ECF bleaching, the viscosity of the final bleached pulp was marginally reduced to $9.7 \mathrm{mPas}$ from $10.3 \mathrm{mPas}$. The ozone treated pulp required less chlorine based bleaching chemicals and attained higher 
brightness, compared to the pulp bleached without using ozone. The improved bleachability of the ozone treated pulp may be due to the better removal of metal ions, compared to that from the pulp bleached without ozone.

Brightness reversion (P.C. number) of the pulp bleached after the ozone treatment was reduced by $34.8 \%$, as compared to ECF bleached pulp without ozone. The reason behind the reduction in brightness reversion may lie in the presence of a lower amount of HexA in the pulp bleached using the ECF sequence with ozone, compared to the pulp bleached without ozone. Other researchers also reported that pulps with higher HexA content are more prone to brightness reversion, ${ }^{31}$ and the use of ozone in prebleaching reduced the brightness reversion by removal of HexA. ${ }^{7}$

\section{Metal ions in pulp}

The effect of introducing ozone in the ECF bleaching of wheat straw pulp on the content of metal ions was evaluated by analysing five main metal ions present in the pulp, i.e. magnesium $(\mathrm{Mg})$, iron $(\mathrm{Fe})$, zinc $(\mathrm{Zn})$, manganese $(\mathrm{Mn})$ and copper $(\mathrm{Cu})$. Metal ion contents in the final wheat straw pulps bleached with and without ozone are shown in Figure 1. The ECF bleached wheat straw pulp exhibited $87 \mathrm{ppm}$ of $\mathrm{Mg}, 216 \mathrm{ppm}$ of $\mathrm{Fe}, 22 \mathrm{ppm}$ of $\mathrm{Zn}, 6 \mathrm{ppm}$ of $\mathrm{Mn}$ and $4 \mathrm{ppm}$ of $\mathrm{Cu}$. Out of the five metals analysed, three metals, namely $\mathrm{Fe}, \mathrm{Cu}$ and $\mathrm{Mn}$, are reported to be the most harmful for pulp bleaching with respect to brightness development, cellulose degradation and chemical consumption. ${ }^{32,33}$ The transition metal ions present in the pulp were reduced substantially in the ozone bleaching stage due to the extremely low $\mathrm{pH}$ (about 2.0) maintained during the treatment. Introducing the ozone stage prior to the ECF bleaching of wheat straw pulp further reduced the $\mathrm{Fe}, \mathrm{Cu}$ and $\mathrm{Mn}$ content in the pulp by $6 \%, 11 \%$ and $31 \%$, respectively. These metal ions come primarily from the raw material and secondarily from contamination caused by the process water and corrosion of the equipment. The presence of these metal ions leads to the decomposition of bleaching chemicals and the formation of non-selective species, which leads to the degradation of polysaccharide chains and thereby loss of pulp viscosity. ${ }^{34,35}$

\section{Hexenuronic acid in pulp}

The content of hexenuronic acid (HexA) present in the unbleached pulps of different raw materials used for making pulp and paper is listed in Table 4. HexA groups are formed in the xylan chains during kraft pulping. These acid groups cause increased consumption of bleaching chemicals, decreased brightness, greater brightness reversion and poorer metal removal. ${ }^{36}$ Wheat straw has HexA content of $13.6 \mu \mathrm{mol} / \mathrm{g}$, which is higher than that of sugarcane bagasse and rice straw, but lower than that of bamboo, eucalyptus and casuarina. Casuarina has the highest HexA content - of $54 \mu \mathrm{mol} / \mathrm{g}$, and sugarcane bagasse the lowest - of $6.6 \mu \mathrm{mol} / \mathrm{g}$. The presence of HexA has an influence on the kappa number of pulp, as permanganate attacks HexA, which therefore contributes to the kappa number of the pulps. The contribution of the HexA content to the kappa number is of 2-7 units, depending on the type of the pulp. ${ }^{37}$ HexA groups consume approximately 8.6 equivalents of potassium permanganate per mole of HexA present in the pulp. ${ }^{38}$ The HexA present in the pulp also reacted with the bleaching chemicals, such as ozone and chlorine dioxide. The reaction rate of ozone with HexA was reported to reach $134 \mathrm{mmol} / \mathrm{kg} / \mathrm{min}$, as compared to 56.8 $\mathrm{mmol} / \mathrm{kg} / \mathrm{min}$, in the case of lignin in oxygen delignified eucalyptus pulp. ${ }^{39}$

Table 4

Hexenuronic acid present in unbleached pulps of different raw materials

\begin{tabular}{lc}
\hline Particulars & Hexenuronic acid content $(\mu \mathrm{mol} / \mathrm{g})$ \\
\hline Sugarcane bagasse & $6.6 \pm 0.6$ \\
Rice straw & $10.8 \pm 0.4$ \\
Wheat straw & $13.6 \pm 0.5$ \\
Bamboo & $18.2 \pm 0.9$ \\
Eucalyptus & $41.5 \pm 2.3$ \\
Casuarina & $54.0 \pm 2.5$ \\
\hline
\end{tabular}




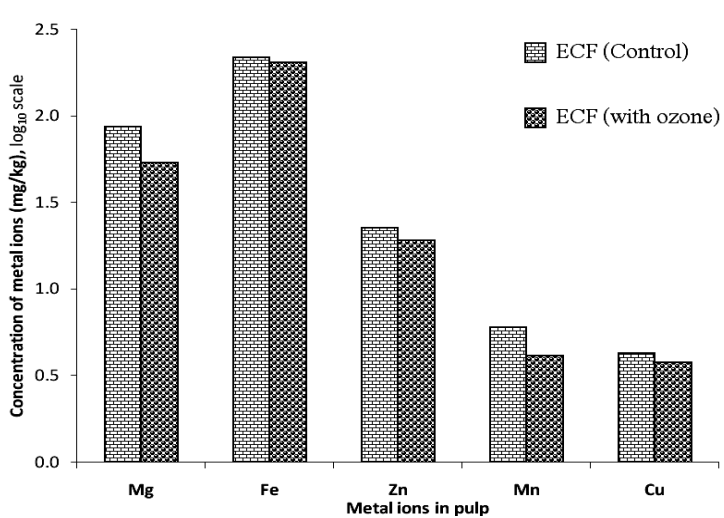

Figure 1: Effect of introducing ozone on metal ions in bleached pulp

The content of HexA in wheat straw pulp at different stages is illustrated in Figure 2. The ODL stage was the least effective in reducing the HexA from the pulp (causing a decrease of 9.0\%), whereas the ozone stage reduced it by $41.1 \%$. The ECF bleaching of ODL pulp and ozone treated pulps reduced the HexA content by $62.3 \%$ and $68.0 \%$, respectively. The additional reduction in HexA content in the ozone treated ECF bleached wheat straw pulp has contributed to an improvement in pulp brightness and whiteness, as well as to a reduction in brightness reversion. Shatalov and Pereira ${ }^{40}$ also reported a reduction of about $67 \%$ in hexenuronic acids recorded during bleaching of giant reed kraft pulp.

\section{Physical strength properties}

The physical strength properties of refined and unrefined ECF bleached wheat straw pulps (with and without ozone) are given in Table 5. For the unrefined pulps, the freeness reached 385 CSF and 360 CSF for the ECF bleached pulp without ozone (control) and the ECF bleached pulp with ozone, respectively. The paper handsheets made from the unrefined control pulp exhibited 43.5 $\mathrm{mN} / \mathrm{g}$ tensile index, $3.6 \mathrm{kN} / \mathrm{g}$ burst index, 7.0

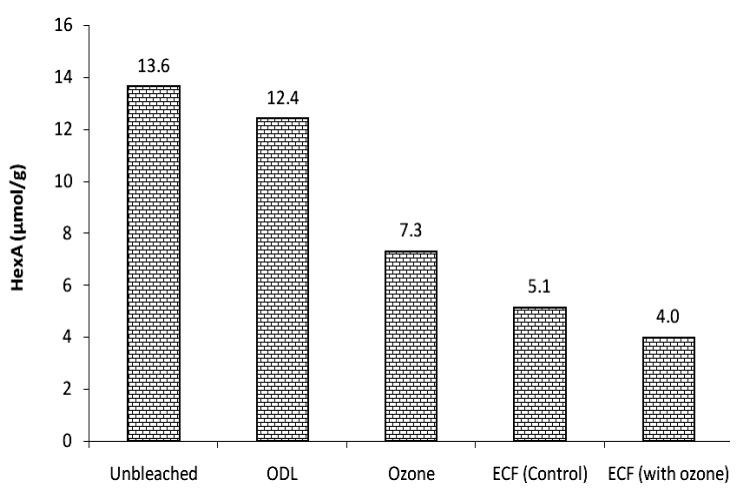

Figure 2: Hexenuronic acid content in wheat straw pulp at different stages

$\mathrm{mN} . \mathrm{m}^{2} / \mathrm{g}$ tear index and 27 double fold numbers. These physical strength properties were improved upon refining, except the tear index. There was no noticeable difference in the physical strength properties of the control and the ECF bleached pulp with ozone. Mishra et al ${ }^{41}$ reported marginal (4.3\%) reduction in the tear index of eucalyptus pulp after introducing ozone in elemental chlorine free bleaching.

\section{Morphological properties}

The morphological properties of the ECF bleached wheat straw pulps (with and without ozone) are listed in Table 6. The ECF bleached wheat straw pulp without ozone exhibited 0.818 $\mathrm{mm}$ average fiber length, $17.5 \mu \mathrm{m}$ mean width and $71.8 \mu \mathrm{g} / \mathrm{m}$ coarseness. The morphological properties of the ECF bleached wheat straw pulp with ozone were comparable with those of the control pulp. Moreover, the major morphological properties reported in this paper are comparable with those reported earlier by different researchers for wheat straw pulp, i.e. average fiber length of $0.66-1.18 \mathrm{~mm}$ and mean width of 13.6-19.32 $\mu \mathrm{m} .{ }^{42-45}$

Table 5

Physical strength properties

\begin{tabular}{lcccc}
\hline \multirow{2}{*}{ Particulars } & \multicolumn{2}{c}{ ECF (control) } & \multicolumn{2}{c}{ ECF (with ozone) } \\
\cline { 2 - 5 } & Unrefined & Refined & Unrefined & Refined \\
\hline PFI revolution (no.) & 0 & 100 & 0 & 100 \\
Freeness (mL, CSF) & $385 \pm 5$ & $320 \pm 5$ & $360 \pm 5$ & $305 \pm 5$ \\
Tensile index (mN/g) & $43.5 \pm 1.3$ & $51.9 \pm 1.5$ & $44.5 \pm 2.4$ & $53.0 \pm 1.6$ \\
Burst index $(\mathrm{kN} / \mathrm{g})$ & $3.6 \pm 0.2$ & $4.9 \pm 0.2$ & $3.9 \pm 0.1$ & $4.9 \pm 0.1$ \\
Tear index $\left(\mathrm{mN} . \mathrm{m}^{2} / \mathrm{g}\right)$ & $7.0 \pm 0.3$ & $6.7 \pm 0.2$ & $7.0 \pm 0.3$ & $6.8 \pm 0.3$ \\
Double fold (number) & $27.0 \pm 2.0$ & $62.0 \pm 8.2$ & $26 \pm 2$ & $60 \pm 3$ \\
\hline
\end{tabular}


Table 6

Morphological properties

\begin{tabular}{lcc}
\hline Particulars & ECF (control) & ECF (with ozone) \\
\hline Mean length $(\mathrm{mm})$ & $0.818 \pm 0.014$ & $0.811 \pm 0.014$ \\
Mean width $(\mu \mathrm{m})$ & $17.5 \pm 0.14$ & $17.4 \pm 0.26$ \\
Coarseness $(\mu \mathrm{g} / \mathrm{m})$ & $71.8 \pm 1.1$ & $69.0 \pm 1.2$ \\
Mean kink angle (degree) & $56.4 \pm 1.3$ & $57.2 \pm 2.8$ \\
Mean kink index & $2.88 \pm 0.1$ & $3.11 \pm 0.5$ \\
Vessels/lakh fibers (no.) & $965 \pm 14.6$ & $830 \pm 12.3$ \\
\hline
\end{tabular}

Table 7

Properties of the effluent generated during pulp bleaching

\begin{tabular}{lcc}
\hline Particulars & ECF (control) & ECF (with ozone) \\
\hline COD $(\mathrm{mg} / \mathrm{L})$ & $1120 \pm 20.5$ & $659 \pm 13.3$ \\
BOD $(\mathrm{mg} / \mathrm{L})$ & $260 \pm 4.2$ & $157 \pm 5.7$ \\
Colour $(\mathrm{PCU})$ & $406 \pm 9.2$ & $171 \pm 4.2$ \\
AOX $(\mathrm{mg} / \mathrm{L})$ & $11.0 \pm 0.3$ & $5.8 \pm 0.2$ \\
\hline
\end{tabular}

\section{Effluent properties}

The properties of the effluent generated during ECF bleaching of the pulps are given in Table 7. The combined effluent generated during bleaching of the control pulp recorded $1120 \mathrm{mg} / \mathrm{L}$ chemical oxygen demand (COD), $260 \mathrm{mg} / \mathrm{L}$ biochemical oxygen demand (BOD), 406 PCU colour level and $11.0 \mathrm{mg} / \mathrm{L}$ adsorbable organic halogens (AOX). The COD, BOD, colour level and AOX were reduced by $41.2 \%, 39.6 \%, 57.9 \%$ and $47.3 \%$, respectively, upon the use of ozone prior to ECF bleaching due to the lower consumption of bleaching chemicals and the reduction in unwanted chemical reactions caused by the removal of metal ions prior to bleaching. Lundah $^{46}$ reported that applying an ozone stage prior to ECF bleaching of eucalyptus hardwood pulp reduced the AOX by $50 \%$ and COD - by $39 \%$, even without re-circulating the ozone stage filtrate in the brown stock washing system. The results of introducing the ozone stage in a mill scale operation demonstrate a $77.5 \%$ reduction in AOX generation per tonne of mixed hardwood pulp produced. ${ }^{47}$

\section{CONCLUSION}

This study concludes that introducing an ozone stage prior to the ECF bleaching sequence of wheat straw pulp improved pulp brightness by 2.5 units and whiteness - by 4.0 units, while reducing the brightness reversion by $34.8 \%$, when compared to the control. The reason behind the improvement in optical properties may be due to the additional removal of metal ions from the pulp, which ultimately reduced the formation of intermediate radicals during pulp bleaching. The introduction of the ozone stage prior to the ECF bleaching sequence of wheat straw pulp results in physical strength properties and morphological properties comparable with those of the control pulp. It also results in improved effluent quality. Introducing ozone in the ECF bleaching reduced the content of transition metal ions in the pulp by $38 \%$, that of HexA - by $21.6 \%$, also decreasing the COD in the bleaching filtrate by $41.2 \%$, BOD - by $39.6 \%$, colour level - by $57.9 \%$ and AOX by $47.3 \%$, compared to the control.

\section{REFERENCES}

1 A. Metais and E. Germer, in Procs. International Pulp Bleaching Conference, Porto Seguro, BA, Brazil, 2017, pp. 1-5.

2 X. Z. Zhang, Y. Ni and A. Van Heiningen, J. Pulp Pap. Sci., 26, 335 (2000).

3 V. B. Medwick, J. S. Gratzl and R. P. Singh, Tappi J., 77, 207 (1992).

4 M. Ragnar, T. Eriksson and T. Reitberger, Holzforschung, $\quad \mathbf{5 3}, 292 \quad$ (1999), https://doi.org/10.1515/HF.1999.049

5 J. Brown, M. C. Cheek, H. Jameel and T. W. Joyce, Tappi J., 77, 105 (1994).

6 T. Kishimato, Ph.D. Thesis, Hokkaido University, Japan, 1996.

7 M. Wennerstrom, Pulp Pap. Can., 106, 41 (2005), https://pdfs.semanticscholar.org/ab15/2c400e26f33cb7 c9c339a09257e46c1662ea.pdf

8 J. C. Hostachy, Tappi J., 9, 6 (2010).

9 V. J. Gomes and J. L. Colodette, Chem. Nova, 40, 54 (2017). 
10 M. B. Roncero, A. L. Torres, J. F. Colom and T. Vidal, Bioresour. Technol., 87, 315 (2003), https://doi.org/10.1016/S0960-8524(02)00225-0

11 J. C. Hostachy, in Procs. $9^{\text {th }}$ International Conference Paperex, New Delhi, India, 2009, pp. 111121.

12 H. Dong, Key Eng. Mater., 753, 249 (2017).

13 S. Tripathi, N. K. Bhardwaj and H. R. Ghatak, Ozone: Sci. Eng., 40, $148 \quad$ (2018), https://doi.org/10.1080/01919512.2017.1352483

14 S. Tripathi, N. K. Bhardwaj and H. R. Ghatak, Ozone: Sci. Eng., 41, $137 \quad$ (2019). https://doi.org/10.1080/01919512.2018.1508331.

15 D. M. Updegraff, Anal. Biochem., 32, 420 (1969), https://doi.org/10.1016/S0003-2697(69)80009-6

16 L. Deschatelets and K. C. U. Errest, Appl. Microbiol. Biotechnol., 24, 379 (1986), https://doi.org/10.1007/BF00294594

17 L. E. Wise, M. Murphy and A. A. D'Addieco, Pap. Trade J., 122, 35 (1946).

18 K. Rakness, G. Gordon, B. Langlais, W. Masschelein, N. Matsumoto et al., Ozone: Sci. Eng., 18, 209 (1996), doi:10.1080/01919519608547327

19 H. W. Giertz, Svensk Papperstidn., 48, 317 (1945).

20 P. S. Lam, S. Sokhansanj, X. Bi, C. J. Lim, L. J. Naimi et al., Appl. Eng. Agric., 24, 351 (2008).

21 Z. Miao, Y. Shastri, T. E. Grift, A. C. Hansen and K. C. Ting, Biofuels Bioprod. Bioref., 6, 351 (2012), https://doi.org/10.1002/bbb.1322

22 R. G. Fernandez, C. P. Garcia, A. G. Lavina, J. L. B. Heras and J. J. Pis, Waste Manag., 33, 1151 (2013), https://doi.org/10.1016/j.wasman.2013.01.033

23 S. V. Subrahmanyam, R. Godiyal, V. Janbade and A. Sharma, Preparation of monograph of different fibrous raw materials used by Indian paper industry, 2004, Central Pulp and Paper Research Institute, Saharanpur, India, http://www.dcpulppaper.org/gifs/ report24.pdf.

24 Z. Kebbi-Benkeder, F. Colin, S. Dumarcay and P. Gerardin, Ann. Forest Sci., 72, 277 (2015), doi.org/10.1007/s13595-014-0428-7.

25 R. C. Sun, D. Salisbury and J. Tomkinson, Bioresour. Technol., 88, $95 \quad$ (2003), https://doi.org/10.1016/S0960-8524(02)00290-0

26 M. T. Garcia, A. Alfaro, J. C. Garcia, M. A. M. Zamudio, A. B. Morales et al., Cellulose Chem. Technol., 51, 465 (2017), http://www.cellulosechemtechnol.ro/pdf/CCT56(2017)/p.465-475.pdf

27 W. Sridach, Sur. J. Sci. Tech., 17, 105 (2010).
${ }^{28}$ U. K. Ghosh, J. Sci. Ind. Res., 65, 68 (2006).

${ }^{29}$ A. Ghosh and Y. Ni, J. Pulp Pap. Sci., 24, 26 (1998).

${ }^{30}$ E. Andrew, J. Johakimu and N. E. Ngema, Tappi J., 12, 9 (2013).

31 V. L. Silva, A. G. Lino, R. A. Ribeiro et al., BioResources, $\quad$ 6, $4801 \quad$ (2011), https://bioresources.cnr.ncsu.edu/BioRes_06/BioRes_0 6_4_4801_Silva_LRCRW_Factors_Brite_Rever_HW_ Kraft_Pulps_1737.pdf

${ }^{32}$ L. Lapierre, M. Paleologou and R. M. Berry, J. Pulp Pap. Sci., 23, 539 (1997).

33 O. Dahl, J. Niinimaki and T. Tirri, in Procs. International Pulp Bleaching Conference, Helsinki, Finland, 1998, pp. 383-388.

${ }^{34}$ A. Wuorimaa, R. Jokela and R. Aksela, Nord. Pulp Pap. Res. J., 21, 435 (2006).

${ }^{35}$ L. Hui, F. Wang, J. Pang and Zhong Liu, Cellulose Chem. Technol., 51, $301 \quad$ (2017), http://www.cellulosechemtechnol.ro/pdf/CCT34(2017)/p.301-306.pdf

${ }^{36}$ Z. H. Jiang, B. V. Lierop and R. Berry, Tappi J., 83, 167 (2000).

37 T. Vuorinen, P. Fagerstrom and E. Rasanen, in Procs. International Symposium on Wood and Pulping Chemistry, Montreal, Canada, 1997, pp. M3 1-3.

${ }^{38} \mathrm{~J}$. Li and G. Gellerstedt, Carbohydr. Res., 302, 213 (1997), https://doi.org/10.1016/S0008-6215(97)001250

${ }^{39}$ G. Ventorim, J. L. Colodette and A. F. Gomes, Wood Fib. $\quad$ Sci., $\quad$ 40, $190 \quad$ (2008), https://wfs.swst.org/index.php/wfs/article/view/1693

40 A. A. Shatalov and H. Pereira, Carbohyd. Polym., 67, 275 (2007),

https://doi.org/10.1016/j.carbpol.2006.05.028

${ }^{41}$ S. P. Mishra, D. Lachenal and C. Chirat, Tappi J., 12, 39 (2013).

${ }^{42}$ C. Ververis, K. Georghiou and N. Christodoulakis, Ind. Crop. Prod., 19, 245 (2004).

${ }^{43}$ S. Guo, H. Zhan and C. Zhang, BioResources, 4, 1006 (2009).

${ }^{44}$ J. E. Kasmani and A. Samariha, Middle-East J. Sci. Res., 8, 823 (2011).

${ }^{45}$ S. Singh, D. Dutt and C. H. Tyagi, BioResources, 6, 154 (2011), https://ojs.cnr.ncsu.edu/index.php/ BioRes/article/view/BioRes_06_1_0154_Singh_DT_C haract_Wheat_Straw

${ }^{46}$ Y. Lundahl, in Procs. $9^{\text {th }}$ International Conference Paperex, New Delhi, India, 2009, pp. 123-130.

${ }^{47}$ K. D. Sharma, Ippta J., 22, 131 (2010). 